\title{
INFLUENCE OF AGE ON SOME BLOOD PARAMETERS OF LAMBS IN ORGANIC PRODUCTION
}

\author{
Zvonko Antunović, Marcela Šperanda, Đuro Senčić, Josip Novoselec, \\ Zvonimir Steiner, Mislav Djidara \\ Faculty of Agriculture in Osijek, Trg sv. Trojstva 3, 31000 Osijek, Croatia \\ zantunovic@pfos.hr
}

\begin{abstract}
The influence of age on changes of some blood parameters has been researched within the blood serum of lambs during the suckling ( $30^{\text {th }}$ day) and fattening period $\left(70^{\text {th }}\right.$ day). Lambs were raised in the organic way. Significantly decreased concentration of calcium $(2.78$ and $2.67 \mathrm{mmol} / \mathrm{l})$, inorganic phosphorus $(3.53$ and $3.10 \mathrm{mmol} / \mathrm{l})$, triglyceride (0.43 and $0.28 \mathrm{mmol} / \mathrm{l})$, total cholesterol (1.67 and $1.04 \mathrm{mmol} / \mathrm{l})$, HDL and LDL- cholesterol (1.10 and $0.73 \mathrm{mmol} / \mathrm{l} ; 0.37$ and $0.19 \mathrm{mmol} / \mathrm{l})$ as well as increased concentration of sodium (149.43 and $152.14 \mathrm{mmol} / \mathrm{l})$, urea (6.89 and $8.66 \mathrm{mmol} / \mathrm{l})$, total proteins $(56.41$ and $59.76 \mathrm{~g} / \mathrm{l})$, albumins $(29.91$ and $31.11 \mathrm{~g} / \mathrm{l})$ and ALT - alanine aminotransferase activity $(9.14$ and $12.14 \mathrm{U} / \mathrm{l})$ were determined in the blood of lambs by increasing age. With increasing the age of the lamb the number of WBC (leucocytes) and RBC (red blood cell) as well as the content of haemoglobin and haematocrite in blood, significantly increased higher content of platelets and MCV as well as lower content of $\mathrm{MCH}$ and MCHC were found in the blood of older lambs in comparison with the youngest lambs. The results of some blood metabolites in the lamb organic production indicate that the age must be taken as a very important factor in determining metabolic profile of blood.
\end{abstract}

Key words: lamb; age; blood; organic production

\section{ВЛИЈАНИЕ НА ВОЗРАСТА ВРЗ НЕКОИ ПАРАМЕТРИ НА КРВТА КАЈ ЈАГНИҢАТА ВО ОРГАНСКОТО ПРОИЗВОДСТВО}

\begin{abstract}
Влијанието на возраста врз промените на некои параметри на крвта беше испитувано во крвниот серум на јагниња во времето на цицање (30-тиот ден) и во периодот на гоење (70-тиот ден). Јагнињата беа одгледувани на органски начин. Со зголемување на возраста кај јагнињата беше забележано значително намалување на концентрацијата на калциум (2,78 и 2,67 mmol/l), неоргански фосфор (3,53 и 3,10 mmol/l), триглицериди $(0,43$ и $0,28 \mathrm{mmol} / \mathrm{l})$, вкупен холестерол $(1,67$ и $1.04 \mathrm{mmol} / \mathrm{l})$, холестерол HDL и LDL $(1,10$ и $0,73 \mathrm{mmol} / \mathrm{l} ; 0,37$ и $0,19 \mathrm{mmol} / \mathrm{l})$, како и зголемената концентрација на натриум (149.43 и $152.14 \mathrm{mmol} / \mathrm{l})$, yреа (6.89 и 8,66 mmol/l), вкупни протеини (56,41 и 59,76 g/l), албумини $(29,91$ и $31,11 \mathrm{~g} / \mathrm{l})$ и ALT - аланинаминотрансферазна активност $(9,14$ и $12,14 \mathrm{U} / 1)$. Со зголемување на возраста на јагнињата значително се зголеми и бројот на WBC (леукоцити) и RBC (црвени крвни клетки), како и содржината на хемоглобин и хематокрит во крвта. Повисока содржина на крвни плочки и $\mathrm{MCV}$, како и пониска содржина на МCH и МCHC беа најдени во крвта на постарите јагниња во споредба со најмладите. Резултатите за некои крвни метаболити во органското одгледување на јагнињата покажуваат дека возраста мора да биде земена како многу важен фактор при одредување на метаболитичкиот профил на крвта.
\end{abstract}

Клучни зборови: јагне; возраст; крв; органска продукција

\section{INTRODUCTION}

Ecological production aims to ensure the optimal interaction between soil-plant-animal and to create sustainable production including local resources (Benoit et al., 2009). A significant problem in ecological livestock production is to ensure optimal meals needed for adequate production and 
maintenance of body condition. This is especially prominent in young animals in the intensive growth, the period of suckling and fattening. Less nutritional errors often remain undetected due to animal consumes its own reserves. Therefore, it often increases production loss and reduces the profitability of production. Before determining the blood metabolic profile that can indicate specific nutritional mistakes (Herdt, 2000; Antunović et al., 2009 ) it is necessary to determine whether there is diversity in blood metabolites, depending on the age of lamb.

The aim of this work was to determine the impact of age on blood metabolite in the organic lamb production.

\section{MATERIAL AND METHODS}

Biological investigations have been made on 20 Merinolandschaft lambs divided in two groups different of age. The influence of age on the concentration changes of some blood parameters has been researched within the blood serum of lambs during the suckling period ( $30^{\text {th }}$ day) and the fattening period $\left(70^{\text {th }}\right.$ day). The lambs were in an equal sex proportion (50\% male : $50 \%$ female), healthy and in good physical condition. Holding the lamb is in the ecological way (Low on organic production of animal products, N.N. 13/02). The lambs in the suckling period were together with sheep, and the lambs in the fattening period in two boxes. Lambs are nourished with a mixture of forage (cereals: corn $-50 \%$, oat $-20 \%$, barley $20 \%$, and soybean $-10 \%$ ).

The blood was collected from the jugular vein $(10 \mathrm{ml})$ into the sterile vacuum tubes Venoject ${ }^{\circledR}$ (Sterile Terumo Europe, Leuven, Belgium). Mineral content $(\mathrm{Ca}, \mathrm{P}$-inorganic, $\mathrm{K}, \mathrm{Na}, \mathrm{Fe}$ and $\mathrm{Cl}$ ), biochemical parameters (glucose, urea, createnine, total proteins, albumin, triglycerides, total cholesterol, HDL-cholesterol and LDL-cholesterol), and activity of enzymes (ALT - alanine aminotransferase, AST - aspartate aminotransferase, CK - creatine hinase, GGT - $\gamma$-glutamyl transferrase, and LDH - lactate dehydrogenase) in blood serum was determined on the Olympus AU640, and the thyroid hormones $\left(\mathrm{T}_{3}\right.$ and $\left.\mathrm{T}_{4}\right)$ were determined by the radioimmunological method on the automatic imunoanalyser IMX-ABBOTT. Determination of hematological indicators (number of leukocytes - WBC, erythrocytes - RBC, and platelet - PLT, as well as the content of haemoglobin and haematocrite, and MCV, MCH and MCHC in the full blood of sheep is carried out on an automatic 3 diff haematological analyser SYSMEX pocH-100iV.

The research results were processed according to the LSD test system software Statistica (StatSoft. Inc., 2008).

\section{RESULTS AND DISCUSSION}

Concentration of potassium, sodium, chloride and iron were within the normal range of variation (Table 1). Concentration of calcium was below and concentration of P-inorganic above the reference values for sheep. Such changes in calcium concentration in the blood of lamb, especially in the fattening period are associated with the lack of calcium in food. Most concentrates are low in calcium. Cereals frequently contain $>1 \mathrm{~g} \mathrm{Ca} / \mathrm{kg} \mathrm{DM}$ (Underwood and Suttle, 2001). Higher concentration of P-inorganic may be related to the structure of meals. Specifically, lamb meal is rich in cereals, and is known as wealth cereal with phosphorus. Furthermore, this difference could be the cause of a lessened capacity to assimilate phosphorus from diet as the age of animals rises (Blood and Radostits, 1993; Sharifi et al., 2005). Kaneko et al. (1997) quoted that the serum phosphate may be higher in younger animals because the growth hormone increases renal phosphate resorption. It is also determined significant $(\mathrm{P}<0.05)$ decrease the concentration of calcium and P-inorganic and increase the concentration of sodium as age increased lamb. Kaushish et al. (2000) and Bornez et al. (2009) came to the similar changes in concentration of minerals. Meyer and Harvey (1992) suggested that higher levels of plasma P-inorganic and calcium in younger animals may be due to higher levels of growth hormone. Mohri et al. (2007) determined the lower concentration of calcium and higher concentrations of chloride and potassium in the blood of growing cattle with rises of age. Concentrations of iron in the blood of lambs were below the reference values of adult sheep. Probably the amounts of body iron reserve and $\mathrm{Fe}$ content of diet are responsible for these differences.

By analyzing the concentrations of biochemical indicators, depending on the time of lamb an increase $(\mathrm{P}<0.05)$ of urea concentration, total protein, albumin, and decrease of the concentration of total, HDL and LDL cholesterol and triglyceride were found (Table 2). Feeding has a signifi- 
cant influence to the urea concentrations in the serum of ewes and lambs (Holcombe et al., 1992; Antunović et al., 2001). Similar observations for urea concentration have been obtained by Kaushish et al. (2000).

Table 1

Concentration of minerals in blood of lambs in organic production

\begin{tabular}{cccc}
\hline \hline Mineral & \multicolumn{2}{c}{ Age $(n=20)$} & $\begin{array}{c}\text { Reference values } \\
\text { (Kaneko et al., } \\
\end{array}$ \\
\cline { 2 - 3 } & $30^{\text {th }}$ day $(\bar{x} \pm \mathrm{s})$ & $70^{\text {th }}$ day $(\bar{x} \pm \mathrm{s})$ & $1997)$ \\
\hline $\mathrm{Ca}$ & $2.78 \pm 0.09^{\mathrm{a}}$ & $2.67 \pm 0.09^{\mathrm{b}}$ & $2.88-3.20$ \\
$\mathrm{P}$ & $3.53 \pm 0.19^{\mathrm{a}}$ & $3.10 \pm 0.43^{\mathrm{b}}$ & $1.62-2.36$ \\
$\mathrm{~K}$ & $4.96 \pm 0.25$ & $5.34 \pm 0.42$ & $3.90-5.40$ \\
$\mathrm{Na}$ & $149.43 \pm 2.07^{\mathrm{a}}$ & $152.14 \pm 1.95^{\mathrm{b}}$ & $139-152$ \\
$\mathrm{Fe}$ & $37.31 \pm 15.42$ & $29.40 \pm 7.79$ & $29.70-39.70$ \\
$\mathrm{Cl}$ & $108.71 \pm 1.98$ & $109.86 \pm 1.95$ & $95-103$ \\
\hline \hline
\end{tabular}

Table 2

Biochemical indicators in blood of lambs in organic production

\begin{tabular}{|c|c|c|c|}
\hline \multirow[b]{2}{*}{$\begin{array}{l}\text { Indicator } \\
\mathrm{mmol} / 1\end{array}$} & \multicolumn{2}{|c|}{ Age $(n=20)$} & \multirow{2}{*}{$\begin{array}{c}\text { Reference } \\
\text { values } \\
\text { (Kaneko et al., } \\
\text { 1997) }\end{array}$} \\
\hline & $\begin{array}{c}30^{\text {th }} \text { day } \\
(\bar{x} \pm \mathrm{s})\end{array}$ & $\begin{array}{l}70^{\text {th }} \text { day } \\
(\bar{x} \pm \mathrm{s})\end{array}$ & \\
\hline Urea & $6.89 \pm 1.51^{\mathrm{a}}$ & $8.66 \pm 0.60^{b}$ & $2.86-7.14$ \\
\hline Glucose & $5.97 \pm 0.62$ & $5.54 \pm 0.37$ & $2.78-4.44$ \\
\hline TP, $\mathrm{g} / 1$ & $56.41 \pm 3.52^{\mathrm{a}}$ & $59.76 \pm 2.44^{\mathrm{b}}$ & $60-79$ \\
\hline Creatinine, $\mu \mathrm{mol} / 1$ & $65.29 \pm 6.21$ & $62.43 \pm 7.30$ & 106-168 \\
\hline Albumine, g/1 & $29.91 \pm 0.97^{\mathrm{a}}$ & $31.11 \pm 1.03^{\mathrm{b}}$ & $24-30$ \\
\hline Cholesterol & $1.67 \pm 0.88^{\mathrm{a}}$ & $1.04 \pm 0.11^{\mathrm{b}}$ & $1.5-2.28$ \\
\hline HDL & $1.10 \pm 0.51^{\mathrm{a}}$ & $0.73 \pm 0.06^{\mathrm{b}}$ & - \\
\hline LDL & $0.37 \pm 0.30^{\mathrm{a}}$ & $0.19 \pm 0.09^{b}$ & - \\
\hline Triglyceride & $0.43 \pm 0.14^{\mathrm{A}}$ & $0.28 \pm 0.05^{\mathrm{B}}$ & $0.0-0.2$ \\
\hline
\end{tabular}

The concentrations of the total proteins and albumin in the blood serum of the lambs have been increased with the advanced age. As the age rises, the concentration of total protein in the blood of sheep increases (Bornez et al., 2009; San Sampelayo et al., 1998). The high total protein content after birth can be a result of serum immunoglobulin content growth and this demonstrates good alimentary canal absorption and has some effect on later clinical state (Baranowski et al., 2000). The cholesterol concentration is influenced by the degree of stress (Schaffer et al., 1981). Therefore, lower cholesterol with age might be expected from stress (particularly by weaning lambs). The higher concentration of urea and albumin and lower concentrations of creatinine and glucose in the blood of growing cattle with rises of age were determined by Mohri et al. (2007). In the investigation Antunović et al. (2005) conducted with the lamb Merinolandschaf breeds at different age identified similar trends for urea concentration, total cholesterol and proteins. The increasing age of lambs increased ALT activity $(\mathrm{P}<0.05)$ and fell activity of GGT, CK and LDH (P > 0.05; Table 3$)$. The conent hormone $\mathrm{T}_{3}(\mathrm{P}<0.01)$ was very significantly lower with increasing the age of lamb, while the content of $\mathrm{T}_{4}$ is not varied depending on the age of lamb ( $\mathrm{P}>0.05)$. The increase of the ALT enzyme with the age is probably a consequence of the body mass increase and intensifying the metabolic activity. Similar observations for the activity of ALT and GGT have been obtained by Ramos et al. (1994). With rises of the cattle age Mohri et al. (2007) determined decreased AST activity.

Table 3

Enzymes activities and thyroid hormones in lambs blood in organic production

\begin{tabular}{lccc}
\hline \hline \multirow{2}{*}{$\begin{array}{c}\text { Indicator } \\
\text { U/1 }\end{array}$} & $30^{\text {th }}$ day $(\bar{x} \pm \mathrm{s})$ & $\begin{array}{c}\text { Reference } \\
\text { values }\end{array}$ \\
\cline { 2 - 4 } & $94=20)$ & $\begin{array}{c}\text { th } \\
\text { AST }\end{array}$ & $\begin{array}{c}\text { Kaneko et al., }(\bar{x} \pm \mathrm{s}) \\
1997)\end{array}$ \\
\hline ALT & $9.14 \pm 3.80^{\mathrm{a}}$ & $12.14 \pm 3.13^{\mathrm{b}}$ & $6-20$ \\
$\mathrm{GGT}$ & $92.57 \pm 19.28$ & $88.00 \pm 15.74$ & $20-52$ \\
$\mathrm{CK}$ & $191.29 \pm 6.99$ & $189.57 \pm 4.61$ & $106-168$ \\
LDH & $590.43 \pm 85.22$ & $506.57 \pm 64.91$ & $238-440$ \\
$\mathrm{~T}_{3}, \mathrm{nmol} / 1$ & $2.56 \pm 0.44^{\mathrm{A}}$ & $1.59 \pm 0.36^{\mathrm{B}}$ & - \\
$\mathrm{T}_{4, \mathrm{nmol} / 1}$ & $101.93 \pm 28.23$ & $102.79 \pm 13.89$ & $54-111$ \\
\hline \hline A,B $: \mathrm{P}<0.01 ;{ }^{\mathrm{a}, \mathrm{b}}: \mathrm{P}<0.05$ & &
\end{tabular}

With increasing age of lamb the number of WBC and RBC as well as the blood content of haemoglobin and haematocrite significantly increased (Table 4). Higher number of platelet content and $\mathrm{MCV}$ and lower content of $\mathrm{MCH}$, and $\mathrm{MCHC}$ were found in the blood of the older lamb in comparison with the youngest lamb. 
Bornez et al. (2009) found in the blood of the lamb at the age of 70 days feed with concentrate and wheat straw a significantly higher number of $\mathrm{RBC}$, higher content of haemoglobin and haematocrite, as well as a greater number of leukocytes unlike the suckling lamb at the age of 30 days. The same authors found even higher content of MCV and $\mathrm{MCH}$ in the blood of the suckling, compared to the fattening lambs. A smaller number of RBC, similar content haemoglobin, and a larger number of WBC in the blood of lambs are found by Njwe and Ngo (1987). Knowles et al. (2000) also found in the blood of calves with increasing age (from birth to 83 days) increase in values of haematocrite, haemoglobin, and $\mathrm{RBC}$ and that can be associated with increased values of the white blood cell (WBC). Mohri et al. (2007) found in the monitoring of the blood composition in calves with increasing age a higher content of $\mathrm{RBC}, \mathrm{WBC}$, PLT, haematocrite and haemoglobin as well as a decrease content of MCV.

Table 4

\section{Haematological indicators in blood of lambs in organic production}

\begin{tabular}{|c|c|c|c|}
\hline \multirow{2}{*}{$\begin{array}{l}\text { Indicator } \\
\mathrm{U} / 1\end{array}$} & \multicolumn{2}{|c|}{ Age $(n=20)$} & \multirow{2}{*}{$\begin{array}{c}\text { Reference } \\
\text { values } \\
\text { (Kramer, } \\
2000)\end{array}$} \\
\hline & $30^{\text {th }}$ day $(\bar{x} \pm \mathrm{s})$ & $70^{\text {th }}$ day $(\bar{x} \pm \mathrm{s})$ & \\
\hline $\mathrm{WBC}\left(\times 10^{9} / 1\right)$ & $5.40 \pm 2.25^{\mathrm{A}}$ & $10.50 \pm 3.82^{\mathrm{B}}$ & $9-15$ \\
\hline $\mathrm{RBC}\left(\times 10^{12} / 1\right)$ & $11.12 \pm 1.66^{\mathrm{A}}$ & $15.99 \pm 3.14^{\mathrm{B}}$ & $9-15$ \\
\hline Haemoglobin $(g / 1$ & $111.71 \pm 10.29^{\mathrm{A}}$ & $149.57 \pm 31.92^{\mathrm{B}}$ & $90-150$ \\
\hline Haematocrite & $0.43 \pm 0.07^{\mathrm{A}}$ & $0.59 \pm 0.13^{\mathrm{B}}$ & - \\
\hline $\mathrm{MCV}, \mathrm{fl}$ & $38.44 \pm 2.12$ & $36.63 \pm 3.02$ & $28-40$ \\
\hline $\mathrm{MCH}, \mathrm{pg}$ & $10.17 \pm 1.33$ & $9.34 \pm 0.62$ & $8-12$ \\
\hline MCHC, g/l & $264.86 \pm 31.78$ & $256.14 \pm 18.88$ & - \\
\hline $\operatorname{PLT}\left(\times 10^{9} / 1\right)$ & $638.50 \pm 195.34$ & $802.14 \pm 447.79$ & 500 \\
\hline
\end{tabular}

\section{CONCLUSION}

The results of blood metabolites lamb in organic production indicate that the age must be taken as a very important factor in determining blood metabolic profile of the lamb.

Acknowledgment. This article is a part of the research project "Possibility of improving the productivity of sheep in organic breeding" financed by the Ministry of Agriculture, Fisheries and Rural Development of the Republic of Croatia.

\section{REFERENCES}

[1] Antunović, Z., Bukvić, G., Steiner, Z., Antunović, M., Rastija, D. (2001): Dynamic of rotation pastures quality and influence on some biochemical indicators in sheep blood. Krmiva, 43: 301-308.

[2] Antunović, Z., Senčić, Đ., Domaćinović, M., Šperanda, M., Steiner, Z. (2005): Changes in some blood parameters associated with the age of lambs. Med. Wet., 61, 7: 761-764.

[3] Antunović, Z., Šperanda, M., Mioč B., Novoselec J., Šperanda T. (2009): Determination of nutritional status of goats in organic production systems. Tieraerztl. Umschau., 64, 1: 18-23.

[4] Baranowski, P., Baranow-Baranowski, S., Klata, W. (2000): Some haematological and biochemical serum and bone tissu indices of lambs derived from ewes fed on vitamin- and mineral-vitamin supplements during pregnancy. Bull. Vet. Inst. Pulawy., 44: 204-214.

[5] Benoit, M., Tournadre, H., Dulphy, J. P., Laignel, G., Prache, S., Cabaret, J. (2009): Is intensification of reproduction rhythm sustainable in an organic sheep production system? A 4-year interdisciplinary study. Animal, 1: $1-11$.

[6] Blood, D. C., Radostits, O. M. (1993): Medicina Veterinaria. $7^{\text {th }}$ ed. Interamericana. McGraw-Hill, Madrid.: 293-1294.

[7] Bornez, R., Linares, M. B., Vergara, H. (2009): Haematological, hormonal and biochemical parameters in lamb: Effect of age and blood sampling time. Liv. Sci., 121: 200-206.

[8] Herdt, T. H., Rumbeiha, W., Braselton, W. E. (2000): The use of blood analyses to evaluate mineral status in livestock. Vet. Clin. North Am. Food Anim. Pract., 16, 423444.

[9] Holcombe, D. W., Krysl, L. J., Judkins, M. B., Hallford, D.M. (1992): Growth performance, serum hormones and metabolite responses before and after weaning in lambs weaned at 42 days of age: Effect of preweaning milk and postweaning alfalfa or geass hay diets. J. Anim. Sci., 70: 403-411.

[10] Kaneko, J. J., Harvey, J. W., Bruss, M. L. (1997): Clinical Biochemistry of Domestic Animals. Academic Press, San Diego, London, Boston, New York, Sydney, Tokio, Toronto, 932.

[11] Kaushish, S. K., Karim, S. A., Rawat, P. S. (2000): Physiological responses and metabolic profile of lambs in growth phase. Indian J. Anim. Sci., 70, 6: 616-618.

[12] Knowles, T.G., Edwards, J. E., Bazeley, K. J., Brown, S. N., Butterworth, A., Warriss, P. D. (2000): Changes in the blood biochemical and haematological profile of neonatal claves with age. Vet. Rec., 147, 21: 539-598.

[13] Kramer, J. W. (2000): Normal haematology of cattle, sheep and goats. In: Feldman, B. F., Zinkl, J. G., Jain, N. C. eds. Schalm's Veterinary Haematology. $5^{\text {th }}$ ed. Baltimore. Lippincot Williams \& Wilkins:1057-1084.

[14] Law on Organic Production of Animal Products (2002): N. N. $13 / 02$.

[15] Meyer, D. J., Harvey, J. W. (1992): Veterinary Laboratory Medicine. Interpretation and Diagnosis, 2nd ed. Saunders, Philadelphia: 201. 
[16] Mohri, M., Sharifi, K., Eidi, S. (2007): Hematology and serum biochemistry of Holstein dairy calves: Age related changes and comparison with blood composition in adults. Res.Vet. Sci., $83: 30-39$.

[17] Njwe R. M., Ngo Tama A. C. (1987): Effect of age on some haematological parameters of indigenous dwarf Blackbelly sheep of Cameroon. Rev. Sci. Tech. Sci. Agric. 3: $147-152$.

[18] Ramos J. J., Verde M. T., Marca M. C., Fernandez A. (1994): Clinical chemical values and variations in Rasa Argonesa ewes and lambs. Small Rumin. Res., 13: 133139.

[19] San Sampelayo, M. R., Lupiani, M. J., Guerrero, J. E., Boza, J. (1998): A comparison of different metabolic types between goat kids and lambs: Key blood constitu- ents at different times in the first two months aftre birth. Small Rum. Res., 31: 29-35.

[20] Shaffer L., Roussel J. D., Koonce K. L. (1981): Effects of Age, Temperature-Season, and Breed on Blood Characteristics of Dairy Cattle. J. Dairy Sci., 64: 62-70.

[21] Sharifi, K., Mohri, M., Abedi, V., Shahinfar, R., Farzaneh, M., Shalchi, M. H. (2005): Serum and whole blood inorganic phosphorus in lambs from birth to 400th day of life: Effect of weaning as a cutoff point between neonatal and adult levels. Comp. Clin. Path, 14: 160167.

[22] Statistica - Stat Soft, Inc. Version 8 (2008): www-statsoft.com.

[23] Underwood, E. J., Suttle, N. F. (2001): The Mineral Nutrition of Livestock. $3^{\text {rd }}$ ed. CABI Publishing, 614. 
